\title{
Introduction: Jonze Between the
}

\section{Lines}

Kim Wilkins and Wyatt Moss-Wellington

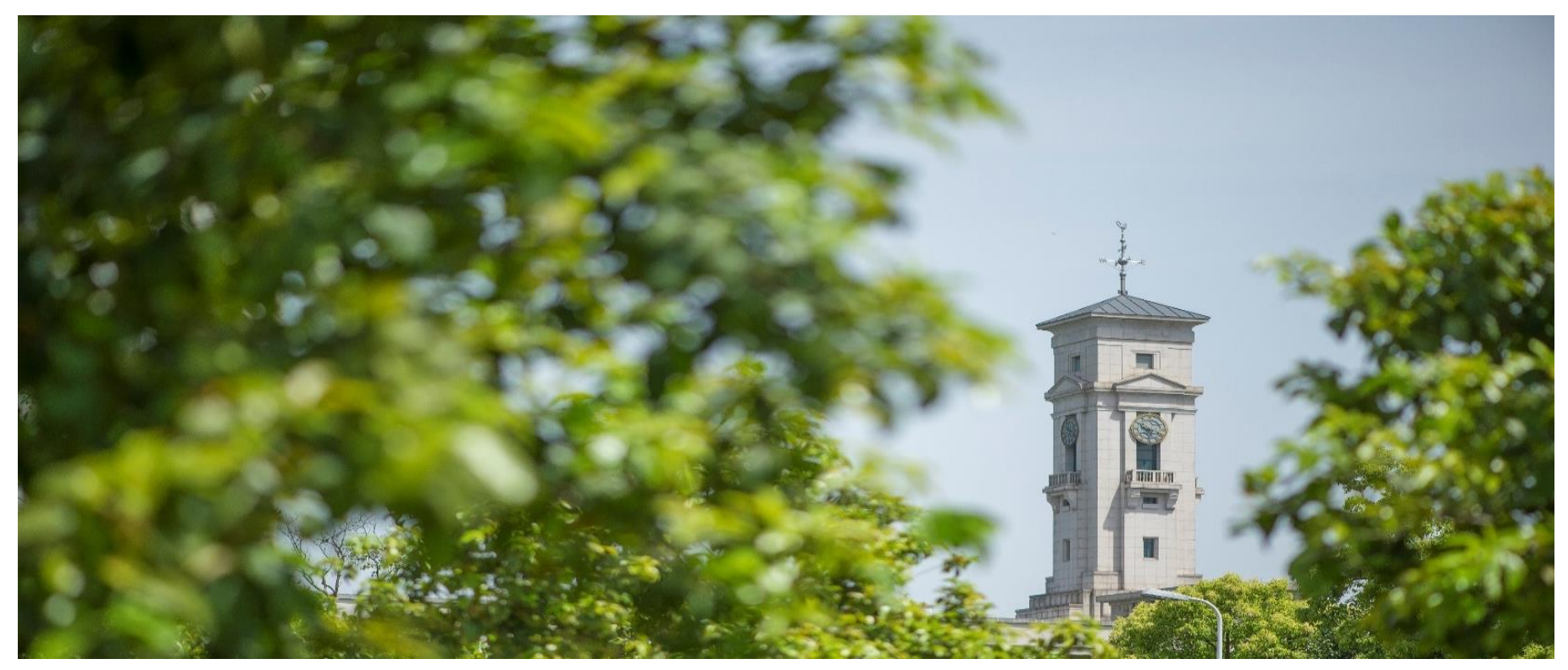


Faculty of Humanities and Social Science, University of Nottingham Ningbo China, 199 Taikang East Road, Ningbo, 315100, Zhejiang, China.

First published 2019

This work is made available under the terms of the Creative Commons Attribution 4.0 International License:

http://creativecommons.org/licenses/by/4.0

The work is licenced to the University of Nottingham Ningbo China under the Global University Publication Licence:

https://www.nottingham.edu.cn/en/library/documents/researchsupport/global-university-publications-licence.pdf 


\section{Introduction: Jonze Between the Lines}

Kim Wilkins and Wyatt Moss-Wellington

The title of this collection may, at first, appear misleading. We promise it is not.

Readers may expect a collection with the title "The Films of Spike Jonze" to present a fairly traditional auteurist study. Claiming films to be "of Spike Jonze" identifies Jonze as an author, and as such echoes the enthusiasm established by the young Cahiers critics whose politique des auteurs celebrated those "[men] of the cinema" whose work could be elevated to the status of high art. ${ }^{1}$ Indeed, the critical discourse tracking Jonze's feature film career conforms to this narrative. From his debut feature Being John Malkovich (1999) to his latest film Her (2013), Jonze's work has been regarded as inventive, surreal, quirky, genius, and, above all, distinctly original — the hallmark of auteurism. ${ }^{2}$ Of Being John Malkovich, Roger Ebert wrote, "Every once in a long, long while a movie comes along that is like no other. A movie that creates a new world for us and uses it to produce wonderful things ... Either 'Being John Malkovich' gets nominated for best picture, or the members of the Academy need portals into their brains." Although Being John Malkovich did not receive a nomination for Best Picture, it was nominated in three other categories, including Best Director. ${ }^{4}$ In addition to the originality of his films, Jonze has been increasingly regarded as a deeply personal filmmaker. Reflecting on Jonze's adaptation of his children's book Where the Wild Things Are, author Maurice Sendak said, “I've never seen a movie that looked or felt like this. And it's [Spike Jonze's] personal 'this.' ... He's a real artist that lets it come through in the work." Jonze's status as a "real artist" with a "personal" vision was a recurring theme in the critical reception of Her — supported by Jonze's singular writer-director credit. ${ }^{6}$

As much as we might take issue with traditional auteurist designations as a means for describing film labor or evaluating a canon (and contributors in this volume certainly do), we 
can still find value in tracing artistic recurrences across a filmmaker's oeuvre without presuming a singular vision heroically transmitted in isolation from - or despite of -

production collaborators. How, then, could we begin to define Jonze's "personal" reference points, those aesthetics and stories the filmmaker continues to return to? We might suggest that across Jonze's four features, a unique style is indeed discernible: that he blends the outlandish and fantastical with mainstream Hollywood conventions, or that his films are philosophical, or that he repeatedly centers his narratives around lonely male protagonists. We might also examine the production histories of his feature films to interrogate his relative autonomy with respect to notions of independence that often accompany auteurism - and indeed, many chapters herein traverse this exact terrain. However, where auteurist accounts of filmmakers focus on directors as artists and authors of feature films, to limit our discussion in this manner would mispresent Jonze's expansive oeuvre. In fact, feature films comprise only one facet of Jonze's creative output.

Prior to Being John Malkovich, Spike Jonze (born Adam Spiegel in October 1969) was known predominantly for his explorative work in music videos for artists including Björk, Sonic Youth, the Beastie Boys, Puff Daddy, Weezer, R.E.M., Ween, Daft Punk, The Chemical Brothers, Pavement, The Notorious B.I.G. and Fatboy Slim. Jonze began his career as a BMX photojournalist and directed a number of influential skating videos, including Video Days (1991). He would maintain a concurrent career in digital media production, TV and online journalism right up to his current role as creative director of Vice Media. This is typical of Jonze's crisscrossing, transmedial reach. His roles in the film industry might be substantial - as director, writer, actor and producer - however Jonze's creative range connects nodes between many other industries, including television production (in particular the Jackass franchise), commercial work and journalism. Thus, rather than delimiting Jonze's creative identity to "director" (or even a "filmmaker") he is a creative with more in common 
with the contemporary "slashie" workers who "straddle industries and disciplines, defining themselves by several professions." "Jonze has always worked between the lines of commercial and subversive imperatives, philosophy and genre entertainment, independent and Hollywood modes of production, short work and features. As such, this volume focuses not simply on the feature films of Jonze, but on his work as a transmedia practitioner in the age of convergence. Where the "auteur" designation has been reserved for singularly distinctive feature film directors - and common parlance employs "film" as shorthand for "feature film" - this collection understands these terms more broadly. The term "film" refers to Jonze's short form audiovisual work, both the commercial and noncommercial, as much as it does his features.

The realigned focus on Jonze as a transmedial practitioner is just one of the ways in which this volume presents his work as "in between," and precipitates a shift in the consideration of film as art — and art as autonomous - particularly distinct from commercial imperatives. As Fabian Holt and Francesco Lapenta write, autonomy is a sine qua non of creative work. ${ }^{8}$ However, the development of the contemporary creative industries within which Jonze operates challenges romantic notions of the artist and autonomy because:

[it] involves a rationalisation of artistic practices into creative products such as media work and design. Artistic work is generally contingent on the rules of art characterised by an emphasis on artistic autonomy and originality, but also a greater resistance to the industrial system. Both creative and artistic work, however, tend to be restrained but never eliminated when absorbed into industrial production ... A certain level of autonomy is necessary to produce creative products of cultural and economic value, but autonomy is not a monolithic concept. Rather, it is constituted in complex relationships between these contradictory and unstable forces. ${ }^{9}$ 
While film, in the Hollywood tradition, has always been a commercial art, the proponents of auteurism have often circumvented or overtly disavowed their selected filmmakers' commercial imperatives. Of course, positioning art in opposition to commerce is not distinct to filmmaking. Citing Pierre Bourdieu, Angela McRobbie notes that for many creatives financial failure is often taken as a marker of artistic success or integrity. ${ }^{10}$ Stephanie Taylor and Karen Littleton term this opposition "the art-versus-money" repertoire wherein creative work and money-making are not only viewed as incompatible, but the latter is considered to pose a variety of threats to the former, even while it may in fact sustain it. ${ }^{11}$

One of the other focuses of this collection is a fusion of seemingly binaristic themes and ideas that characterize Jonze's films; metaphysics and play, sentimentality and existentiality, speculative fiction and naturalist aesthetics all coexist and at times vie openly for prominence. For instance, one might note the tone of Being John Malkovich as wryer or cheekier than the majority of philosophy pictures released in 1999, which tended to more somber affective landscapes. Being John Malkovich set some emotive groundwork that would sustain: a union of the playful with unabashedly philosophical excursions marked his future filmmaking, from the metafilm as existential comedy in Adaptation (2002) to meditations on early development and the seriousness of play in Where the Wild Things Are (2009), and finally the fusion of leisure and entertainment (and even a Jonze-voiced videogame) with our most intimate selves in $\operatorname{Her}(2013) .{ }^{12}$ Similarly, a flirtation with - and gradual embrace of - narrative sentimentality extends throughout these four pictures. After the relatively unsentimental Being John Malkovich, Adaptation probed some critical uses of sentimental Hollywood modes, Where the Wild Things Are mobilized this sentimentality in talking through youth and familial disturbance, and Her remains reflexive about media and sentimentality, while admitting sentiment as part of a common phenomenal experience in our 
daily machine-human interactions. This growing acceptance of the sentimental can be witnessed across some of Jonze's most substantial short film work, too: I'm Here (2010), for instance, is a distilled and unrestrained romantic sentimentality again mapped onto a near science fiction future. ${ }^{13}$

In addition to Jonze's incremental admittance of sentimental modes, another intriguing component in these pictures is a moral ambivalence that runs throughout. After Being John Malkovich, which presents characters who are terrifyingly quick to dismiss the ethical dimensionality of inhabiting the other, appropriation and embodiment, Adaptation dramatized Charlie Kaufman's open and unresolved question regarding the kinds of stories he ought to be telling as a Hollywood screenwriter, Where the Wild Things Are found a way to adapt the sweet-natured relativism of affordances we make to youth during their moral development that anchors Sendak's source material, and Her neither moralizes at its audience about their attachment to new media, nor unthinkingly accepts it. ${ }^{14}$ Finally, working in between worlds of speculative fiction and aesthetic realism is another nexus that characterizes Jonze's work. ${ }^{15}$ The familiarity of the office spaces in Being John Malkovich is offset against its more outlandish spatial convolutions; Adaptation moves between fantastical imagery of earth's development and a more mundane domesticity; Where the Wild Things Are explicitly crosses from the real world to the make-believe, yet the lingering influence of each of these worlds remains inseparable, while cinematographer Lance Acord's naturalist lighting helps blur their distinction; and Her works in the tradition of humanistic science fiction that presents a future in which everyday interactions remain ordinary, even while technological change renders their iteration extraordinary. ${ }^{16}$ All of Jonze's features retain traces of science fiction, but splice their speculation with realist aesthetics and concerns that are relevant to our quotidian ethical selves. 
These diverse films have been categorized by critics in many ways, not simply as works of an auteur, but as works of resistance against a populist mainstream, as part of an American "smart cinema" or even a filmic "new sincerity". ${ }^{17}$ There is, of course, trouble with attempts to slot Jonze neatly into a movement, as again, he crosses filmmaking modes: which two films could be more different than Bad Grandpa and Her, projects Jonze worked on concomitantly? ${ }^{18}$ We might note small amounts of "leakage" between the different genre worlds that Jonze traverses.

The most widely adopted theorization of the formal and aesthetic strategies indieauteur filmmakers employed around the turn of the millennium is Jeffrey Sconce's "smart cinema."19 Alongside Jonze, Sconce identified Todd Solondz, Neil LaBute, Alexander Payne, Hal Hartley, Wes Anderson, P.T. Anderson, Ang Lee, John Herzfeld, Doug Liman, Atom Egoyan, Todd Haynes, Richard Kelly, and Richard Linklater as filmmakers whose work responded to the increasing prevalence of irony and parody in cultural discourse. For Sconce, these auteurist films demonstrated a smart cinema sensibility through "a predilection for irony, black humour, fatalism, relativism and, yes, even nihilism." ${ }^{20}$ As many of the authors in this collection find, however, Jonze's films do not exhibit strong nihilist or even fatalist inclinations. Rather, they navigate feelings of isolation, the tribulations of interpersonal relationships (with both human and nonhuman subjects), and existentialism. Nevertheless, Jonze's work can be read in concert with the prevalence of ironic expression in American popular culture, and the fusion of mainstream generic conventions with philosophical considerations that characterize many "smart" films.

Indie cinema rhetoric tends to echo these sentiments by positioning its practitioners in a quasi-oppositional relationship to the dominance of Hollywood, emphasizing distinctive economic models, modes of production, storytelling and audiovisual aesthetics, and variances in distribution, exhibition, and audience reception. ${ }^{21}$ Michael Z. Newman writes that this 
relationship to Hollywood in turn creates and perpetuates an indie film culture that sees itself as more culturally legitimate and sophisticated than mainstream cinema, in that it has the potential for counter-hegemonic representation and political change. ${ }^{22}$ This formulation has perpetuated the "indie-auteur" ideal, which identifies specific (overwhelmingly male) filmmakers as "mavericks" or "rebels" whose work deviates sufficiently from mainstream conventions that they are —ironically—said to "take back" or legitimate the Hollywood system of filmmaking. ${ }^{23}$ Jonze was identified as a member of such a group of "renegade auteurs" that emerged in the 1990s. These filmmakers where seen to be "tweaking the system" 24 by creating films that emphasized their "braininess" over mainstream genericity through intertextual engagement with popular culture, reflexivity, achronological plot structures, and overt use of irony. ${ }^{25}$ Yet even in comparison to contemporaries, Jonze's cinema exhibits distinctive tendencies that can be mapped across his oeuvre, both in terms of style and thematic interest - and it is the divergences rather than the similarities that intrigue. Jonze's works are full of contradictions that refuse to be tamed so easily, which is what makes his films ripe for closer study.

As Claire Perkins writes, the "smart" indie-auteur harkens back to the New Hollywood era "of 1967-75, whose male mavericks, like Arthur Penn and Terrence Malick, have been similarly cast as forging an adventurous new cinema that linked the traditions of classical genre filmmaking with the stylistic innovations of European art cinema" and is often "credited with the transformation of commercial filmmaking into a better, more artistic type of popular fare." 26 Much of the critical discourse around Jonze and his work supports the "maverick myth" and thus facilitates assigning him indie-auteur status. However, as Yannis Tzioumakis and Andrew Stubbs explain in their respective chapters, the production realities of Jonze's work complicate and push back against the neat application of this idealized label. Furthermore, Jonze's openly collaborative practice in both his feature films (most notably 
with writers Charlie Kaufman and Dave Eggers) and, more overtly, in his short form films complicates the notion of the "personal vision" of a "renegade" artist.

There is no easy way to identify Jonze in the either-or terms of art versus commerce. Jonze is, of course, the creative director of a commercial media company who continues to direct spots for dominant brands, and at the same time makes films that invite the viewer to question the very foundations of media and technology convention. Static narratives neatly summarizing Jonze's career seem slippery given counter-evidence that is always lurking nearby. This spirited battle, regarding the ways in which we might comprehend Jonze as commercially bound or artistically distinct, runs as an open dialogue throughout the collection.

In light of such debates, we would like to suggest one other phenomenon within the space of millennial American filmmaking that Jonze's work exemplifies. At the turn of the millennium philosophy came to the fore in a subset of popular American cinema. Films including Donnie Darko (2001), I Heart Huckabees (2004), Eternal Sunshine of the Spotless Mind (2004), and Linklater's expository dialogue in works like Waking Life (2001) gave philosophy on film a starring role; not just in character dialogue or as a background to onscreen events, but as part of the fabric of the narratives themselves. So within this canon, we suggest that there could be another designation, too: the millennial "philosophy film," comprising features overtly wearing philosophic ambitions on their respective sleeves. As Indiewood historians have pointed out, 1999 presented something of a watershed moment for the intersection of aesthetics and thematic content inherited from independent cinema with Hollywood modes of production. ${ }^{27}$ Given that temporal landmarks generally spur searches for personal meaning, it might seem unsurprising that such interrogative cinema developed when it did. ${ }^{28}$ Yet no matter how they might have dated, the films of 1999 would resonate as landmarks in cerebral filmmaking for years afterwards: consider Magnolia, American Beauty, 
The Sixth Sense, The Virgin Suicides, Three Kings, and those prominent fusions of the visceral and cerebral Fight Club and The Matrix, for instance. It was within this milieu that Jonze directed Being John Malkovich, a film simultaneously identified as a high-minded example of a contemporary "absurdist" cinema, working from the likes of Luis Buñuel's The Discrete Charm of the Bourgeoisie (1972), and a work of "pure-pop fantasia," all of which points to a generic and affective cross-pollination evident in Jonze's philosophy-on-film. ${ }^{29}$

These are just some of the thematic, aesthetic and industrial in-betweens explored across the present volume. In short, Jonze's film work explores the intermedial, the fuzzy, and the transitional, just as his career spans varied media. As Cynthia Felando puts it in her chapter on Jonze's shorts, “Jonze's career demonstrates the depth and breadth of a filmography that ranges not only from shorts to feature films, but fiction to documentary (including mockumentary), black-and-white to color, and live-action to animation.” Jonze truly works between the lines in ways that are sometimes original, and sometimes troubling.

The twelve essays in the collection are divided into four parts. The first two, “Authorship and Originality" and "Psychology, Identity and Crisis," group some of the major concerns that recur throughout Jonze's film oeuvre. "Authorship and Originality" looks at the questions of narrative process embedded in his cinema, including concerns of industry, auteurism and adaptation, as well as some reflection on the production history that made Jonze's early feature experiments possible. Wyatt Moss-Wellington opens the collection with a close look at Adaptation's treatment of Darwinian themes, exhuming from the film an ambitious theory that aligns biological and narrative evolution. His analysis prompts questions regarding Darwin's use in the humanities (in literary and cinematic Darwinism), and ultimately asks how we can know when we are engaged with original thinking, or when we have created something hermeneutically new. Eddie Falvey's chapter on Where the Wild Things Are then describes a particular instance of textual hybridity; the chapter bridges the 
concerns of narrative theory and narrative industry, inquiring into the fruitful exchange between literature and cinema as they fuse with the reverence that is distributed around classic texts - in this case, a picture book that has assumed mythic proportions. Yannis Tzioumakis closes the section, moving from concerns of authorship to those of industry, and fraught notions of American independent cinema. Tzioumakis historicizes the production history of Jonze's first feature Being John Malkovich, situating the film within discourses on the emergence of an "indiewood" cinema.

Following this, "Psychology, Identity and Crisis" homes in on themes of human psychology, masculinity and loneliness, schism and celebrity, and existentialism that recur across his works; these essays aim to tease out some of the latent motifs and formal properties of Jonze's cinema. Picking up on Tzioumakis's historical work on Being John Malkovich, Kim Wilkins extends the debate around "indiewood" to consider claims of innovation, convention and celebrity that frame Being John Malkovich, both in its structure and content, as well as its reception. She describes Craig's (John Cusack) inability to connect with others as indicative of Jonze's lonely male protagonists - a character convention that Julie Levinson then describes in detail. Levinson's chapter on Adaptation makes a strong case for understanding the film within the canon of male midlife crisis comedies. This chapter finds that masculinity in crisis was a thematic strand many of Jonze's contemporaries returned to across the early 2000s. If you stop after reading Levinson's chapter and tilt your head a little, you might catch a glimpse of an original screenplay nestled halfway between parts of the book. This chapter follows up on Moss-Wellington's opening piece, putting the "Adaptation" thesis into practice: it hybridizes the rigor of scholarly style and the imaginative openness, action and atmosphere of the screenplay, asking questions of Jonze's screenwriting, collaboration and the editing process. This explorative chapter reflects another 
facet of Jonze's filmmaking that conventional works of criticism might not easily access: his playful experimentalism.

The penultimate section is dedicated to Jonze's most discussed and celebrated film, Her. Being the only feature to date that Jonze has both written and directed, Her represents a crystallization of the filmmaker's diverse aesthetic and philosophical interests and offers a rich indication of Jonze's authorial tendencies, elaborating on many of the philosophic interests broached in his previous three features: issues in identity and personhood, gender relations, mental health and the origins of life, for instance, are fused with contemporary questions of technology and data, industry and surveillance. The first two chapters, contributed by Peter Marks and Frances Shaw respectively, can be read as a dialogue on the film's representations of empathy, intimacy, and technology, while Richard Smith closes the section with a broader overview of the ways in which Her extends aesthetics developed by Jonze across his shorts and previous three features. Marks's chapter uses the film to ask how we can distinguish the authenticity of emotions in a mediated age that renders the genesis and ownership of emotions diffuse; along the way, he addresses the increasing corporate role in mediated intimacy, problems in the attribution of "feeling" to machines, and the borrowing and repurposing of emotions in the age of big data. Shaw then queries the ethics of big data as they relate to another intimately personal quality: our mental health. Most importantly, she asks what fantasies of artificial intelligence underscore our attempts to outsource therapeutic and empathic work to machines, and explores how these imaginaries relate to other problems within the film, such as the gendered nature of emotional labor and relational surrogacy. Smith outlines three kinds of "movement" that have recurred across Jonze's work and their emergences in Her: the lines of motion created by a skateboard, ontic movement between real and imaginary worlds, and social "movements" through which former modes of 
communication are displaced and reevaluated. Smith's analysis of the similarities between Her and Jonze's short works bridges this section to the final part of the book.

"Beyond the Feature" looks further into Jonze's work in short forms, in particular music videos and the short film. These concluding chapters examine his position as a filmmaker on the blurred boundaries between studio and independent modes of production, and the multi-skilled nature of his practice across media. Cynthia Felando offers an overview of Jonze's short film work, documenting his recurring themes and aesthetics, and making a case for some of the original ideas the filmmaker brought to the short form. Andy Stubbs then contests this originality, positioning notions of artistic autonomy squarely as marketing discourses proffered by the music video production companies that represented Jonze during his early career - Propaganda and Satellite. Stubbs argues that these companies relied upon a narrative of their talents' creative progress toward filmic "indie-auteur" statuses that ultimately devalues the work of music video and short filmmaking. Finally, Laurel Westrup takes a close look at Jonze's collaboration with Arcade Fire on The Suburbs short film and music video, considering notions of nostalgia, suburbia and youth in America along the way. Westrup explores the in-between spaces of adolescence, as they exist in Jonze's collaborative music work.

The twelve chapters that make up this collection are varied in consideration and approach, as warranted in a study of a multifaceted creative like Jonze. Yet this is not to suggest that it is an exhaustive or definitive account—not least because Jonze continues to expand his oeuvre. Instead, "The Films of Spike Jonze" seeks to understand Jonze and his work as it exists "in between" established socio-cultural, philosophical, industrial, and theoretical frameworks. Rather than a diagnostic auteurist study that may encourage a unilateral relationship between author and reader, the chapters that follow are best approached as a live network of intersecting conversations. Although this book has a finite 
number of pages, the conversations they establish, we hope, are ongoing and multidirectional; in the spirit of Jonze's filmmaking, we invite all readers to explore and extend this dialogue into their own conversations in their own worlds.

\footnotetext{
${ }^{1}$ François Truffaut, "A Certain Tendency of the French Cinema," in Movies and Methods,
} Vol. I, ed. Bill Nichols (Berkeley: University of California Press, 1974), 224-237.

${ }^{2}$ See, for instance: David Germain, “At the Movies: Being John Malkovich” Associated Press, October 26, 1999, https://www.apnews.com/f7939f52669edc0203ad58df719de392, David Ansen "Meta-Movie Madness" Newsweek, December 8, 2002 https://www.newsweek.com/meta-movie-madness-140989, Rodney Appleyard, "Wild at Heart” Inside Film: If, No. 127, Dec 2009: 26-28., James Bell, “Computer Love” Sight and Sound, 24:1 (2014) 20-25.

${ }^{3}$ Roger Ebert, “Being John Malkovich” Rogerebert.com, October 29, 1999, https://www.rogerebert.com/reviews/being-john-malkovich-1999

${ }^{4}$ Best Supporting Actress (Catherine Keener), Best Director (Spike Jonze), Best Original Screenplay (Charlie Kaufman).

${ }^{5}$ Sendak qtd. in Chad Perman, "Wild at Heart: On Spike Jonze's Where the Wild Things Are", Bright Wall/Dark Room, Issue 47: Childhood, http://www.brightwalldarkroom.com/2017/05/09/wild-at-heart-on-spike-jonzes-where-thewild-things-are ${ }^{6}$ See: Bell, Mara Reinstein, “Oscars 2014: The 5 Must-See Films” US Weekly, January 11, 2014. https://www.usmagazine.com/entertainment/news/oscars-2014-the-5-must-see-films2014111/, Christoper Orr, "Why Her Is the Best Film of the Year" The Atlantic, December 20, 2013 https://www.theatlantic.com/entertainment/archive/2013/12/why-em-her-em-is-thebest-film-of-the-year/282544/ 
${ }^{7}$ Rachel Olding, "Straddle, not struggle, as slashies prove ultimate multi-taskers" The Sydney Morning Herald, April 23, 2011, https://www.smh.com.au/national/straddle-notstruggle-as-slashies-prove-ultimate-multi-taskers-20110422-1drhg.html ${ }^{8}$ Fabian Holt \& Francesco Lapenta "Introduction: Autonomy and Creative Labour", Journal for Cultural Research, 14:3 (2010), 223-229

${ }^{9}$ Ibid., 225.

${ }^{10}$ Angela McRobbie, British Fashion Design: Rag Trade or Image Industry? (London and New York: Routledge, 1998), 6.

${ }^{11}$ Stephanie Taylor and Karen Littleton, “Art Work or Money: Conflicts in the Construction of a Creative Identity" The Sociological Review, 56, no.2 (2008), 280-282.

${ }^{12}$ C.f. Victor Turner, From Ritual to Theatre: The Human Seriousness of Play (New York: Performing Arts Journal Publications, 1982).

${ }^{13}$ See also Eric Eidelstein, The Suburbs (New York: Bloomsbury Academic, 2017), passim. ${ }^{14}$ Maurice Sendak, Where the Wild Things Are (New York: Harper \& Row, 1963).

${ }^{15}$ There are relatively few articles about the place of Jonze within filmic science and speculative fiction, although Eva-Lynn Jagoe touches on this area in "Depersonalized Intimacy: The Cases of Sherry Turkle and Spike Jonze," English Studies in Canada 42, no. 1 (2016): 170 .

${ }^{16}$ For more on the naturalist aesthetic of Where the Wild Things Are, see Mary Anne Potts, "Where the Wild Things Are: Nature Calls the Shots on a Wild Rumpus in Australia," National Geographic, October 23, 2009, https://www.nationalgeographic.com/adventure/adventure-blog/2009/10/23/where-the-wildthings-are-a-wild-rumpus-in-australia

${ }^{17}$ Jeffrey Sconce, “Irony, Nihilism and the New American 'Smart' Film," Screen 43.4 (2002): 349-369. In film studies, “New Sincerity” usually refers to Jim Collins's description 
90s genre cinema as a rejection of irony and return to sincerity. See "Genericity in the 90s: Eclectic Irony and the New Sincerity" in Film Theory Goes to the Movies, ed. Jim Collins, Hilary Radner and Ava Preacher Collins (New York: Routledge, 1993), 242, 245; Mark Olsen, "If I Can Dream: The Everlasting Boyhoods of Wes Anderson," Film Comment, 35, no. 1 (1999), 12-17. However, Jonze's work does not reject irony in favor of sincerityinstead his films bind irony and sincerity. As such, Jonze (like many of his contemporaries) more accurately fits the form of "New Sincerity" theorized by Adam Kelly to describe the work of authors such as Dave Eggers and David Foster Wallace. See, Adam Kelly, "David Foster Wallace and the New Sincerity in American Fiction." Consider David Foster Wallace: Critical Essays, edited by David Hering (New York: Sideshow Media Group, 2010)131-46; Kim Wilkins, American Eccentric Cinema (New York: Bloomsbury Academic, 2019). ${ }^{18}$ Tim Robey, “Spike Jonze Interview,” The Telegraph, February 3, 2014, https://www.telegraph.co.uk/culture/film/starsandstories/10610048/Spike-Jonzeinterview.html

${ }^{19}$ Sconce, "Irony."

${ }^{20}$ Ibid., 350 .

${ }^{21}$ Michael Z. Newman, Indie: An American Film Culture (New York: Columbia University Press, 2011), 1-2.

${ }^{22}$ Ibid.

${ }^{23}$ See, Sharon Waxman, Rebels on the Backlot: Six Maverick Directors and How They Conquered the Hollywood Studio System (New York: HarperCollins, 2015), James Mottram, The Sundance Kids: How the Mavericks Took Back Hollywood (London: Faber and Faber, 2006). Emmanuel Levy, Cinema of Outsiders: The Rise of American Independent Film (New York: New York University Press, 1999), Derek Hill, Charlie Kaufman and Hollywood's 
Merry Band of Pranksters, Fabulists and Dreamers: An Excursion Into the American New Wave (Harpenden: Kamera Books, 2008).

${ }^{24}$ Armond White, “American Soul, Aisle Five” New York Press 39.no.17 (2004). N.p.

${ }^{25}$ See Kim Wilkins, American Eccentric Cinema

${ }^{26}$ Claire Perkins, "Beyond Indiewood: The Everyday Ethics of Nicole Holofcener." Camera Obscura: Feminism, Culture, and Media Studies 29. 1 (2014): 140.

${ }^{27}$ Geoff King, Indiewood, USA: Where Hollywood meets Independent Cinema (London; New York: I.B. Tauris, 2009), 191-192.

${ }^{28}$ Hengchen Dai, Katherine L. Milkman, and Jason Riis. "Put Your Imperfections Behind You: Temporal Landmarks Spur Goal Initiation when they Signal New Beginnings," Psychological Science 26, no. 12 (2015): 1927-1936; Adam L. Alter and Hal E. Hershfield, "People Search for Meaning when they Approach a New Decade in Chronological Age," Proceedings of the National Academy of Sciences 111, no. 48 (2014): 17066-17070.

${ }^{29}$ Dennis Lim, "Brain Humor: Playing Head Games with the Director, Writer, and Star of Being John Malkovich," Village Voice, October 26, 1999, 46. Rebecca Ascher-Walsh, "Being John Malkovich," Entertainment Weekly, August 20, 1999, 44. 